\title{
Different Concepts of Customer-Supplier Relationship - An Exploratory Case Study of Korean-German Business Activities in the Shipbuilding Industry
}

\author{
Jinchul Choi* \\ * Department of European Studies, Korea Maritime University, Busan 606-791, Republic of Korea
}

\begin{abstract}
In the last several years, South Korea's shipbuilders have been dominating global shipbuilding. Thus, many global suppliers in the shipbuilding industry, especially German supply companies, are eager to get the Korean major shipbuilders as their customer. This study analyzed the different ways of business behaviours of German and Korean businessmen regarding customer-supplier relations. Furthermore, this paper aims to examine the kinds of challenges the international businessmen are confronted with and how this affects everyday business between German suppliers and Korean customers, using several case examples. Finally, backgrounds of cross-cultural problems and conflicts of German-Korean business relations are identified and explained.
\end{abstract}

Key words : cross-cultural management, intercultural business communication, customer-supplier relationship, qualitative research, customer relationship management( CRM), Korean-German business relation

\section{Introduction}

Internationally acting supplier companies are facing growing global competition, which is the reason why their international customers' expectations are getting increasingly demanding. Supplying companies in the shipbuilding sector always put high value on the quality of their products, still they hardly consider the well-being of their customer relations. Thus, for an internationally recognized manufacturer of shipping plants, who aims at gaining access to a foreign market, it is not sufficient simply to care about the mere delivery of technically perfect machinery. From the very beginning the manufacturer has to deal with questions regarding a type of relation it will have with the customers on the foreign market, and find out how different the targeted customers are from those in its home country. If concepts and expectations of the supplier and his customers on the foreign market are not correlating concerning their business relation, it can get much more difficult to gain access to this market than initially estimated by the supplier.

These aspects will be investigated using the cases of a business relation between internationally operating German manufacturers of industrial goods and their Korean customers in the shipbuilding industry. This study aims at identifying the cultural differences affecting KoreanGerman customer-supplier relations, and identifying possible causes and the development of these cultural differences. Furthermore, different concepts of customersupplier relations from the Korean and German side are investigated concerning their effectiveness.

This paper will focus on the situation of a meeting point between commercial enterprises from Germany and Korea within the frame of a customer-supplier relation. Here, the challenges and problems, employees of these German companies are facing when dealing with Korean industrial customers, are especially considered. First, the basic situation of the field research is introduced. Subsequently, the German-Korean interactions in business relations in the shipbuilding industry are analyzed through the analysis of qualitative field research, considering the way German and Korean employees handle cultural differences during their everyday business, as well as the question how business is affected by this situation.

\section{Research of customer-supplier relations}

In research of international business relations, the relation between customers and suppliers (or sellers) is a

* choi1@hhu.ac.kr 051)410-4858

Note) In this text, the terms 'Korea' and 'Korean' always refer to the Republic of Korea (South Korea). 
frequently examined field, e.g. Kale and Barnes (1992), who deal with the topic 'cross-cultural buyer-seller interaction'. The two authors tried to create a framework for a 'cross-national selling transaction' and identified three levels significant for business communication, on which interaction between buyers and sellers coming from different cultures takes place: the levels 'national character', 'organizational culture' and 'individual personality'. Furthermore, Skarmeas et al. (2002) analyzed how the importer's and exporter's commitment influences the intercultural buyer-seller relation. Dwyer et al. (1987) dealt with the development process of the buyer-seller relation.

In cross $^{-}$cultural research, especially concerning US-American-Japanese business relations, the role of the negotiation partner' is emphasized as being 'one of the most important factors for negotiation success' (see Graham, 1984; 1985; Adler and Graham, 1989). Also the vertical relation between customers and sellers, which is common in Japan, plays a major role. Already more than 20 years ago, Nancy J. Adler (2002) dealt with this research field in her publication 'International Dimensions of Organizational Behavior'. She put special emphasis on the buyer-seller relation between the USA and Japan. According to Adler (ibid. 215ff.), the hierarchic relation between customers and sellers is decisive for understanding the various negotiation styles between the different cultures. Japanese customers and sellers stay in a vertical hierarchic relation called 'indulgent dependence': generally most of the expectations and requirements of Japanese customers will be satisfied, while sellers usually expect their customers to support them. In contrary, customers and sellers in the USA stay in a non-hierarchic, almost horizontal relation called 'independent competition'. It would be entirely unimaginable for an American customer to have similarly high expectations as a Japanese customer in the same situation. Considering the different customer-supplier relations based on Adler's concepts of 'indulgent dependence' vs. 'independent competition', it is evident that comprehension of various constellations of relations is the key to understanding that negotiation problems or conflicts are not necessarily due to a lack of product or service quality but emerging from cultural differences.

Together with his colleagues, the US-American economist John L. Graham (1988) analyzed the determining factors of buyer-seller negotiations in four different cultures of the Asian-Pacific area in the frame of a simulation study. 138 US-American, 54 Taiwanese, 42
Japanese and 38 Korean businessmen, having more than two years business experience, where asked to act as buyers and sellers in intracultural negotiation simulations. The result showed that buyers could achieve advantageous results only in Korean and Japanese negotiation situations.

Many researchers investigated buyer-seller and customer-supplier relations in international business; however, most of these previous studies were restricted to prescriptive and quantitative approaches and hardly included the perspective of the individual actors interacting in cross-cultural business situations, both on the customer's and on the supplier's side. More importantly, there are only a few empirical studies to date explicitly treat intercultural customer-supplier business relationshiprelated issues (Moosmueller, 1997; Lamming, 2000). Therefore, this paper will present a descriptive and qualitative approach, including the perspective of individual actors in cross $^{-}$cultural business communication.

\section{Methodology}

\subsection{Research design}

Given the paucity in intercultural customer-supplierrelated research, I chose to provide initial qualitative data and thereby contribute to a deeper understanding of this business relation. Qualitative research can be regarded as a complement to quantitative methods of inquiry by helping to understand the nature of the respective unit of analysis. Yet, the applicability of qualitative research is much more comprehensive. The profound link between the collected data and the phenomenon under study as well as the richness of the data allow a consideration of contextspecific factors, complex patterns and even casual relationships. Thus, qualitative research serves as a valuable means to discover and generate theory that is deeply grounded in empirical reality, particularly when little is known on the underlying phenomenon and research cannot rely much on past empirical findings (Miles and Huberman, 1994, Mayring, 2002).

Building on these ideas, an exploratory qualitative case study with embedded units of analysis was conducted to identify important issues in terms of German-Korean business relations in the shipbuilding industry that seem fruitful to pursue. An exploratory research strategy is especially beneficial in narrowly investigated scientific fields as it reveals emergent themes and thus extends the understanding of the investigated phenomenon. Furthermore, case study research explores a phenomenon that is 
embedded in its context and is therefore particularly fruitful when the boundaries between phenomenon and context are not clearly discernible. This was considered to be an important aspect in order to take into account the wide array of contextual factors inherent in international and cross $^{-}$cultural research. Also, it enabled me to consider the potential impact of firm-specific variables by examining customer-supplier relations of different German Multinational Corporations (below MNCs) acting in Korea.

To strengthen the resulting inferences, I decided to apply a comparative case study design since this method permits data from several cases to be examined in an iterative manner. The iterative process of analyzing

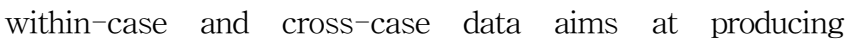
relevant new variables and relationships as well as exploring theoretical explanations for these emerging relationships.

Building on existing literature in the field of international business relations in general and customer-supplier relations in particular, I derived three broad research questions to structure this study. The objective of this research was to investigate cultural differences affecting Korean-German customer-supplier relations in the shipbuilding industry, to explore the conventional origins of the differences in terms of this kind of business relation, and to interpret the empirical cases based on the different concepts of the business relations. At the end it will be pursued to give lessons learned for better business interactions between German and Korean companies.

\subsection{Case selection}

As this research deals with international business activities at MNCs, I chose internationally operating German companies in the shipbuilding industry, which have at least a Korean company unit and are actively operating in the Korean market as one of the important buyer countries in the world. Since the 20th century, shipbuilding has grown as an important and strategic industry in a number of countries around the world. Therefore, shipbuilding is an attractive industry for developing nations. Japan used shipbuilding in the 1950s and 1960s to rebuild its industrial structure; South Korea started to make shipbuilding a strategic industry in the 1970s, and China is now in the process of repeating these models with large state- ${ }^{-}$supported investments in this industry.

South Korea is the world's largest shipbuilding nation with a global market share of 37,45\% in 2011. South Korea is the global leader in the production of advanced high-tech vessels such as cruise liners, super tankers, LNG carriers, drill ships, and large-sized container ships. In the 3rd quarter of 2011, South Korea won all 18 orders for LNG carriers, 3 out of 5 drill ships and 5 out of 7 large-sized container ships (see Kyunghyang Shinmun, Oct. 19. 2011). South Korea's shipyards are highly efficient, with the world's largest shipyard in Ulsan operated by Hyundai Heavy Industries slipping a newly-built, \$ 80 million vessel into the water every four working days. South Korea's 'big three' shipbuilders, Hyundai Heavy Industries, Samsung Heavy Industries, and Daewoo Shipbuilding \& Marine Engineering, dominate global shipbuilding, with STX Shipbuilding, Hyundai Samho Heavy Industries, Hanjin Heavy Industries, and Sungdong Shipbuilding \& Marine Engineering also ranking among the top ten shipbuilders in the world. Thus, many global suppliers in the shipbuilding industry have been eager to get the Korean major shipbuilders as their customer. As already mentioned above, this study aimed at explicitly considering the effects of cultural differences in international business activities from the shipbuilding industry (especially between supplier and customer companies).

The MNCs also differed with regard to their internationalization strategy (Perlmutter, 1969). It is widely believed that the management philosophy towards the firm's foreign operations is a crucial determinant of MNC management in general and multinational staffing decisions in particular. In this regard, the German MNCs in the shipbuilding industry still pursues an ethnocentric or $\mathrm{HQ}^{-}$-centered approach. For example Hermann Kotthoff (2001: 143), who based on an empirical study found out that most of the German internationally operating companies are still oriented on the ethnocentric strategy with regard to mother-daughter-relations: 'In fact, there is a social and cultural space that pluri-locally spans headquarters and dependencies, but in our case studies this 'transnational social space' was very ethnocentric. It had nothing to do with the notions of 'transnational' or 'global' companies normally used in the management literature. The companies are still 'made in Germany'.'

Among the European countries, Germany is a trading nation with high level of exports, a shipping nation, a coastal and port state, and at the same time traditionally a major location for shipbuilding, maritime technologies and so on (see BMVBS, 2011: 5). There are a lot of global leading supplier companies in the shipbuilding sector. Thus, I chose German MNCs as research field. From this point of 
view, German shipbuilding supply companies can be considered prototypical for European companies in the same industry sector. The marine equipment supply sector in Germany is dominated by small and medium sized companies which operate in a global market, with a significant share of employment dependent on experts to the Asian shipbuilding sector (Weber, 2006: 13). Consequently, German companies were selected for this study, in order to investigate what will happen if German suppliers and Korean Customers meet each other for doing business and how the employees cope with cultural differences in terms of customer-supplier relation on their business activities.

\subsection{Data collection}

One part of the field research was carried out in summer 2009 for the period of four weeks in the line with a maintenance seminar for Korean engineers of a Korean shipbuilding company taking place at the training center of a German supplier company G1. ${ }^{1)}$, a global provider of marine equipment, spare parts and services to the shipping and offshore industry. I participated in this seminar as interpreter for the Korean employees of the Korean shipbuilding company K1. During this seminar I had various tasks. First, I worked as interpreter between the Korean trainees and the German trainers and employees of the company G1. Secondly, I acted as cross- ${ }^{-}$cultural consultant for G1 who intended to use a successful seminar for its Korean customer as opportunity to keep its successful operation in the Korean Market. Additionally, I was constantly needed as assistant, travel guide or organizer for the Korean trainees of K1 with whom I was accommodated in the same hotel throughout the four-week period.

The second part of the field research was carried out for the period of one year (2011) in South Korea in a Korean subsidiary of a German multinational company G2, who is one of the world market leaders for large diesel engines used in ships and power stations. I participated as cross-cultural consultant for the Korean employees and German expatriates of G2. I intentionally chose this company as a new case study field, because it was also a German supplier in shipbuilding industry. In doing so, I intended to take into account the possible differences of customer-supplier relations on international business of different German companies. My main task was to give an intercultural training for the Korean employees and the German expatriates of G2 for a successful cooperation between them. I also accompanied the German employees during their business meetings at Korean customer companies. And I had the chance to observe everyday business activities at the Korean subsidiary of G2.

In my position as one of the company members at both German companies for a certain task (interpreter and cross $^{-}$cultural trainer) I could watch everyday processes in German-Korean business interactions. The important aspects were not only what employees say, but also what they do. As organizational researcher I tried to discover, describe and analyze the unpredictable and unexpected phenomena appearing in international business activities. To address the research questions, I conducted open-ended and mostly unstructured interviews (Mayring, 2002) with German and Korean Managers and employees of the German companies. Since the major focus of this study was on the different concepts of business relations, these informants served as units of analysis and the main target of the study. Given the objective to be exploratory and thus to collect rich evidence, a special focus was placed on using narratives. By employing this approach, the interviewer does not present standardized questions but rather encourages the interviews to freely respond and contribute to the topic. This enables the researcher to discover relevant new issues as well as to identify and understand complex behaviors and relationships.

\section{Case examples from German-Korean business relations}

In the following section I would like to introduce the results of my participant observation during the both business projects mentioned above. It will be focused on the statements of my informants of the companies which I researched, especially in terms of customer-supplier relations in their business interactions. The results of this exploratory study can be categorized into three major themes that seem to play an important role within Korean-German customer-supplier relations based on iterative comparison of the field data. First, I report evidence concerning difference of hierarchy in the business relations. Second, I present findings with regard to the relation between German Headquarters and Korean

1) The company names mentioned in this text are anonymized as follows:

1) Field research in Germany - G1: German supplier company, K1: Korean customer company

2) Field research in South Korea - G2: German supplier company, K2: Korean customer company 
subsidiaries which has a great influence on the relation with local customers. The final third part deals with specific influencing factor regarding customer satisfaction. The way German and Korean employees handle the different concepts of customer-supplier relations will be identified, as well as the consequences on everyday business. Concurrently, the various perspectives of German and Korean employees are compared.

\section{Hierarchy}

The training seminar in Germany concentrated on ship-to-shore container cranes. The following example is taken from my participation as interpreter throughout a four-week seminar, and makes clear the different ways technical systems and processes are conceptualized by plant producers (supplier) and users (customer). One of the Korean technicians enquired whether it would be possible to produce parts of the plant in a more solid way so that the crane could be operated for a longer period without replacing service parts, so the German trainer asked for the amount of containers the crane will annually deliver from ship to shore. The following discussion revealed the way the Korean technician and the German trainer considered the plant:

The Korean technicians: 'A crane should not stand still. The container volume will be reduced if the crane is out of order. We maintain and clean the machine regularly according to our rules and know-how, we had collected throughout the years of working with this machinery. The handling according to the instructions can be done only theoretically, but in practice on site it is almost impossible.'

The German trainers: 'After a certain operating time the maintenance and lubricating works have to be carried out. Worn out components have to be replaced on time, so that the machine can operate well for a long time. A daily maintenance and cleansing after operation is required. If certain components are replaced after the prescribed period and regularly lubricated, the crane will operate optimally and on a long term.'

Due to this discrepancy, one of the Korean technicians doubted if the seminar in Germany would really be advantageous for his company in Korea. The Korean technician had participated in a similar seminar at the same academy of the German container-crane producer already 10 years earlier, and might have called himself as 'old hand'. Now he considered the seminar as too formalized, which he put in the following words: 'The training program is part of the contract, that's why it happens. We don't have high expectations as we already know this machine very well due to more than 10 years of experience. This seminar does not at all correspond to our everyday practice.' Contrary to theory, described in the documentation, the practice sometimes reveals operating variations and unexpected problems with the plant. It is very likely that Korean operators have gained a certain 'practical know-how', derived from countermeasures they had to develop after some incidences with the plant which required their improvisation.

Here, the German technicians' attitude becomes evident: they see themselves as 'holder of know-how' offering their technology to Korean customers, which means they have to teach Korean operators how to handle the machine. But from the Korean perspective it is understood that German technicians consider Korean operators as customers they have to serve and satisfy in a most polite way. From the German side, however, it is absurd to adapt their behaviour to the respective kind of business relation.

\section{Parent Company and foreign subsidiary}

These different attitudes among Koreans and Germans often caused conflicts between the employees of the German home office and the employees of the Korean subsidiary. During a customer meeting in Korea, dealing with a quality problem of a product of the company G2, a German engineer asked me several times who will pay for the Korean employee of G2 and whom he is working for. From his perspective, the Korean colleague obviously worked for the customer, as he did not act loyally to his German colleagues during the negotiations with the customer. After several disagreeable questions by the customer, the Korean employee of the company G2 even heated up the situation by asking his colleagues even more critical questions than the customer. The German engineer felt very uncomfortable and commented on the situation as follows:

'Something has to be done here. If the Korean colleague continues like this we will get a heavy problem. He gives false information to the customer and simply agrees on issues our technical department could never allow. Because of the lacking technical knowledge of the Korean and also because of wrong information our company will have to face unexpected situations in the Korean business. It is for me absolutely necessary to discuss this problem with my boss in Germany.'

The Korean employee of the company G2 justified his behaviour as follows: 
'In the Korean way an employee of a supplier is casually formulated - a servant of the Korean customer, who has to do everything for the customer, satisfy the customer day and night and who cannot simply say 'no' to the customer. If you now say 'yes', everything will work out, even if it turns out later to be impossible.'

From the German engineer's point of view, his Korean colleague does not fulfill his task properly. The Korean employee from the subsidiary of the company G2 should defend the quality issue and represent the attitude of the home office, but - from the German perspective - he acted as if he was the customer's employee, whereas the Korean gave his best within the frame of Korean business logic to keep up the business with the Korean customer.

\section{Customer Satisfaction}

Competition on the Korean market is growing, which motivated the customer $\mathrm{K} 2$ to ask for a price reduction from the German supplier G2. If the company G2 could not achieve the price level of local suppliers, company K2 would replace the German supplier by a Korean competitor as there is a Korean supplier aiming at entering the business with a more attractive offer. The German manager of G2 responsible for the East Asian area reacted to this request as follows:

'The request of $\mathrm{K} 2$ to reduce the price is for us not acceptable. But I would like to find a compromise. We could step by step reduce our annual price, but we will never get to the price proposed by the customer. Otherwise we will need another project carried out with him. Only if $\mathrm{K} 2$ promises a certain business volume, the annual price reduction is possible.'

Just as company G2, company G1 pursued a similar strategy. At the interview, the sales manager of the company G1 said:

'In my experience Korean customers demand too much. From my perspective, they have too many requirements and special wishes concerning the ordered products. So far, we have tried to fulfill all kinds of expectations of the Korean customers, still we have got only one project. It would be good to talk about further projects with this customer. Then our company can make a clear decision how to implement further requirements of the Korean customer.

For both German suppliers, the question of future business opportunities was crucial for the evaluation and estimation of the investment value as well as the possible realization of a price reduction or numerous customer requirements. This means for both German suppliers that the readiness of the customer to realize another offer is the most important aspect for the investment decision. From the Korean perspective, however, the present satisfaction of the customer is most important in order to decide upon further projects even if this would mean to accept a deficit for the while. A Korean training participant of the company $\mathrm{K} 1$ held the following opinion:

'We are a company reimbursing those suppliers for their expenses that try to satisfy their customer. If the suppliers work hard for their customer they will get an appropriate reward.'

However, German suppliers are usually not ready to invest in an 'unlikely' future, even if it could turn out to be advantageous later. Concerning countless special requirements and price negotiations with the Korean customer a German manager of the company G1 mentioned:

'We only sell one plant. It is not sure if the future sales increase will happen, therefore there is not much we can do. We cannot deliver our plant at this unreasonably low price.'

From the German perspective it is very common for a supplier company to offer the same fixed price at the same conditions to every customer and to make as few exceptions as possible. German suppliers therefore tend to adapt their products to a market not until they are entirely convinced of the necessity and reasonableness of the customer's special change requests.

Both described incidences of business German-Korean projects make clear that German suppliers and Korean customers, respectively the Korean employees of the German subsidiary, have different concepts of and expectations to their business relations.

\section{Results: Interpretation}

The examination and iterative comparison of the interview and observation data reveal several issues that seem to play an important role in terms of different concepts of customer-supplier relations between German and Korean business partners. The following paragraphs will present the major findings. Simultaneously, the results will be contrasted with existing literature in order to further substantiate the emerging themes and theoretical inferences. In addition, it will be tried to find out the causes or origins of different concepts of business relations which we could observe in the last section. 
5.1 Hierarchic relations between customer and supplier

A typical feature of Korean companies is the asymmetric relation between customers and suppliers: 'Generally, Korean companies are structured in a strong hierarchic system. Communication happens according to these hierarchies, also between supplier and customer. Business processes are oriented along these structures and therefore generally not very flexible or efficient.' (Schoefer, 2001: 262).

In everyday business life in Korea it is common to treat the communication partner according to the social status. The buyer, considering himself as being in a higher position, likes to be served by the seller. Employees of a service center, for example, usually address the calling customer with 'Gogaek-Nim' (customer + the most respectful Korean suffix 'Nim'). There are eight different honorific forms of address, depending on age, sex, degree of relationship or social status (Chang, 1993: 44). Also in the European languages, there are common rules how to address a communication partner, but they cannot be compared to Korean rules. In Korean companies 'vertical person-to-person relations' tend to be common. The patriarchal management style, prevalent in Korean daily business, causes the relation between employer and employees to be comparable to the relation between a patriarch (or father) and his minor children within a family. Through this special relation, the patriarch can act with absolute authority; still a certain caring attitude towards the obedient family members is expected. This management style can be characterized as overall exercise of power together with acceptance of social responsibility. Two basic elements are evident: the absolute authority of the company, and secondly the caring function of the employer towards his employees (see Gaugler, 1969: 118). These two elements can also be found in customersupplier relations. Korean customers and suppliers are in a relationship of mutual dependency. Customers can exercise their authority and mastery, whereas suppliers are obliged to obey the customer. As a reward, customers take up a caring attitude. The scope of this care is depending on the supplier, canvassing for the customer. Out of this situation a feeling of solidarity emerges, a kind of community of fate between customers and suppliers in Korea. (No further explanations are necessary to prove that this causes significant problems to foreign suppliers.) Quality, functioning and concept of a plant are still the most important criteria for deciding upon a plant supplier; still, the Korean customer additionally likes to be sure that the supplier will always do his best - after all, this will be the decisive factor for the Korean customer. As a consequence, the contract is not always awarded to the best supplier but to the one, who presented the highest commitment during the evaluation.

Contrary to this inter-dependent customer-supplier relation, German business partners aim at establishing a 'partnership sourcing' relation to their Korean customers, i.e. a customer-supplier relation using high product quality to make both sides competitive for the world market, regardless of company size or status (see Lamming, 2000). Asymmetric relations between business partners should be avoided from the outset.

Korean customers, however, are used to Korean suppliers who unconditionally fulfill their wishes. From the Korean perspective, customer-supplier relations consist of a business relation between Korean industrial customers and their suppliers. Korean major customers are such companies, playing a pioneering role in Korean economy, e.g. car and electronics manufacturers. The suppliers' group is made up of small and medium sized manufacturers of accessories or capital equipment; their turnover is almost entirely depending on Korean major enterprises. As the existence and well-being of small and medium sized companies is dependent on the customers' goodwill and power, their only chance to survive is to serve the customer like a 'master'. Some major companies even require exclusive contracts of their suppliers. Among car producers it is very common to have a contract with a local supplier (i.e. automotive supplier); this supplier works almost exclusively for this company and carries out the biggest part of the volume of orders for a certain component. In Korea, it is generally known that car producer A cooperates with supplier a, producer B with the supplier $\mathrm{b}$, and producer $\mathrm{C}$ with the supplier $\mathrm{c}$. This situation requires that suppliers will accept a subordinate 'servant' role to the customers. Bilateral relations between both sides experienced significant change due to Korea's economic policy, still these 'master-servant' relations between major companies and their trade partners remain valid. Korean industrial customers will apply this business logic also to commercial activities with foreign suppliers. It is therefore very difficult for a foreign supplier to enter into a business. Misunderstanding and conflicts between German and Korean business partners can be traced back to these differing implicit business concepts and logic of relations of the involved individuals. 
The following table ${ }^{2)}$ represents their experiences and their views of German and Korean informants of the both researched companies relating to cultural differences in customer-supplier relation.

Table 1 Attitudes of German and Korean suppliers from Korean and German perspective

\begin{tabular}{|l|l|l|l|}
\hline \multicolumn{2}{|c|}{ German supplier } & \multicolumn{2}{c|}{ Korean supplier } \\
\hline $\begin{array}{l}\text { According to } \\
\text { Korean }\end{array}$ & $\begin{array}{l}\text { According to } \\
\text { Germans }\end{array}$ & $\begin{array}{l}\text { According to } \\
\text { Korean }\end{array}$ & $\begin{array}{l}\text { According to } \\
\text { Germans }\end{array}$ \\
\hline $\begin{array}{l}\text { Sees } \\
\text { customer as a } \\
\text { petitioner }\end{array}$ & $\begin{array}{l}\text { Sees } \\
\text { customers as a } \\
\text { partner }\end{array}$ & $\begin{array}{l}\text { Customer is } \\
\text { god }\end{array}$ & $\begin{array}{l}\text { Customer is } \\
\text { almighty god }\end{array}$ \\
\hline $\begin{array}{l}\text { Doesn't accept } \\
\text { extra requests } \\
\text { without good } \\
\text { reasons }\end{array}$ & $\begin{array}{l}\text { Accepts } \\
\text { extra } \\
\text { requests when } \\
\text { necessary }\end{array}$ & $\begin{array}{l}\text { Always accept } \\
\text { requests }\end{array}$ & $\begin{array}{l}\text { accepts even } \\
\text { damaging } \\
\text { extra requests }\end{array}$ \\
\hline $\begin{array}{l}\text { Reacts slowly } \\
\text { to customer's } \\
\text { needs }\end{array}$ & $\begin{array}{l}\text { Reacts } \\
\text { as quick } \\
\text { as possible }\end{array}$ & $\begin{array}{l}\text { Reacts very } \\
\text { fast to } \\
\text { customer's } \\
\text { needs }\end{array}$ & $\begin{array}{l}\text { Frantic } \\
\text { reaction to } \\
\text { customer's } \\
\text { needs }\end{array}$ \\
\hline $\begin{array}{l}\text { Basic attitude: } \\
\text { unfriendly, } \\
\text { inflexible }\end{array}$ & $\begin{array}{l}\text { Basic attitude: } \\
\text { friendly, } \\
\text { flexible }\end{array}$ & $\begin{array}{l}\text { Basic attitude: } \\
\text { serving, caring }\end{array}$ & $\begin{array}{l}\text { Basic attitude: } \\
\text { submissive }\end{array}$ \\
\hline
\end{tabular}

As a summary, the customer-supplier relations in Korea and Germany are compared, following the mentioned case examples.

Table 2 Customer-Supplier Relationship in Germany and Korea

\begin{tabular}{|c|c|}
\hline German Relationship & Korean Relationship \\
\hline $\begin{array}{l}\text { Customer dominates supplier: } \\
\text { Supplier employs opportunism; } \\
\text { Relationship is thus combative. } \\
\text { This results in risk premia and } \\
\text { higher costs in supply chain. }\end{array}$ & $\begin{array}{l}\text { Customer dominates suppliers: } \\
\text { Supplier cedes autonomy } \\
\text { Relationship is thus co-operative. } \\
\text { Supplier is compliant and process } \\
\text { costs are reduced. }\end{array}$ \\
\hline $\begin{array}{l}\text { Customers and suppliers rarely } \\
\text { linked in ownership. }\end{array}$ & $\begin{array}{l}\text { Customer and supplier often } \\
\text { linked by equity exchange; this } \\
\text { creates feeling of mutual destiny. }\end{array}$ \\
\hline $\begin{array}{l}\text { Annual price increase is sought by } \\
\text { supplier for long-running items. } \\
\text { Traditional negotiation is seen as } \\
\text { central feature of relationship. }\end{array}$ & $\begin{array}{l}\text { Costs and prices reduce } \\
\text { continually. This helps customer } \\
\text { to compete internationally, while } \\
\text { increase in level of business } \\
\text { makes it bearable for suppliers. }\end{array}$ \\
\hline $\begin{array}{l}\text { Suppliers fend for themselves. If } \\
\text { supplier falls behind, customer } \\
\text { resources. Alternatively, customer } \\
\text { buys supplier to gain total control. }\end{array}$ & 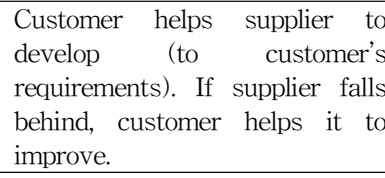 \\
\hline $\begin{array}{l}\text { Relationships characterized by } \\
\text { mistrust; customer's initiatives } \\
\text { for improvements viewed } \\
\text { cynically by suppliers. }\end{array}$ & $\begin{array}{l}\text { Customers tend to deal with } \\
\text { small number of direct suppliers. } \\
\text { Requires first-tier to deal with } \\
\text { second tier and so on. }\end{array}$ \\
\hline $\begin{array}{l}\text { Customers deal with many } \\
\text { suppliers; firms have little loyalty } \\
\text { to each other. }\end{array}$ & $\begin{array}{l}\text { Some } \\
\text { to dea }\end{array}$ \\
\hline
\end{tabular}

\subsection{Different concepts of politeness}

In general, German companies pay relatively less attention to the way their employees communicate with international customers, they rather concentrate on the quality of their export products. Some studies dealt with the question of German companies' 'service mentality'; still, these studies neglect the differing concepts of the terms 'service' or 'politeness towards the customer'. The publicist Seelmann (2006) published an essay dealing with the various concepts of the term 'politeness' in Europe and East Asia. She asks the introducing question: 'Is it actually possible to define 'politeness', being every culture's central category, without taking into account the cultural context?' She points out that Europe and East Asia have entirely different origins of this category. In the European cultural context, 'politeness' derives from good behaviour at a royal court, which is understood as decent, elegant and exemplary, whereas the Korean concept of politeness does not derive from court customs but from the socio-philosophic teachings of Confucius.

In Europe, politeness used to serve as distinguishing mark to set apart noble circles from other social levels. As certain behavioural patterns were taken up by bourgeoisie, they found their way into society as general desirable conventions. Feudalism as political order has long been abolished, still the concept of politeness prevailed as universal human quality. Symmetric relations and equality are self-evidently presumed. Respectful and helpful behaviour is generally considered as polite. In contrast to this European concept, Korean politeness consists of a comprehensive structure of meanings, one of the main pillars of Confucianism basing on ' $\mathrm{Ye}$ ' directing the relation between gods and humans as well as interhuman relations. Behavioural patterns derived from ' $\mathrm{Ye}$ ' are dominated by awe. From this concept basic ethics developed, controlling interpersonal relations between ruler and subject, father and son, man and woman, senior and younger brother, and friends. This conception gained even more influence than the legal order ${ }^{4)}$. Relations content both a vertical hierarchy and a horizontal equality of rights. Everybody has to act according to his age and social status and can expect the same behaviour from others. Today's concept of politeness in Korea is still based on this relational pattern consisting of asymmetric human relations. A Korean professor is addressed by his students

2) Alois Moosmueller (2003: 210) also dealt with this issue. He summarized the way Japanese customers perceive suppliers from the three countries Germany, USA and Japan. The perception of Korean and Japanese customers is very similar and can be compared. 
with special politeness; in the opposite, the professor will act more benevolent and caring. The asymmetric relation can be applied to various levels, like a customer-supplier relation. The supplier should approach the customer with fine politeness and best service, not the other way round. The customer, however, will react to this politeness and service accordingly and behave in a caring way throughout the cooperation.

The reasons why Germans put less emphasis on service culture can be found not only in people's attitude but also in sociolinguistic and institutional aspects. Language reflects the perspective from which the world is perceived (see Whorf ${ }^{5)}$, 1964). In German language, the terms 'service' and 'politeness' evoke rather negative associations. Ebert (2006: 63) published recommendations for professional business communication as follows: 'Service' and 'to serve' mean 'help' and 'to help' on the one hand, on the other hand they also represent a relation based on order and obedience.' Ebert's analysis of the typically German expression 'The customer is king.' reveals the way the German customer-supplier relation is actually considered, the following three 'pitfalls of the monarchist perception':

1) If there is a king, there are also servants. There is an asymmetric relation, the communication partners are not equal.

2) The promise 'Our customer is king.' is often used to hide a certain reluctance to really serve a customer, the own advantage is predominant.

3) If this verbal image is taken literally, it can be interpreted as a misunderstood concept of customer closeness. After all, the customer is not the measure of all things.

The perception of the German customer-supplier relation is obviously not based on an asymmetric relation, the emphasis on the act of serving can be understood in a negative way. Nees (2000: 42) interprets the 'German service problem' as follows: 'Traditionally the official German class system served as the prime creator of social Ordnung, structuring German social life until 1918, when it ended with the emperor's abdication.' According to Nees, Germans could free themselves from monarchist and aristocrat domination, still they keep the attitude that it is humiliating to serve somebody. The lacking service culture in Germany can therefore be traced back to this historic burden. In Germany, the service sector is generally seen as inferior or waste of time.

As a summary, it can be said that Koreans consider asymmetric relations between customers and suppliers as natural, based on their Confucian background, whereas Germans tend to reject unequal relations due to their historic background. The way, German suppliers, the companies G1 and G2, and their Korean customers, the companies $\mathrm{K} 1$ and $\mathrm{K} 2$, perceive their relation to each other and common discussion fields, is very different.

\subsection{Specific backgrounds of Korean economic development}

In Korea, the influence of institutions like state, military, church and family has much more impact on business structures and personnel management than in other countries. From the 1960ies to the end of the 1980ies South Korea was under authoritative military governments, two of which came into power through a military coup. Former military governments concentrated mainly on quantitative economic development, which is the reason for rapid economic growth throughout the 1970ies and 1980ies. 'Sang-Myeong-Ha-Bok' literally means 'command from above, obey from below'. This principle is very common in all social areas, especially in big companies. The source of authoritative company and business structures can be found in Japanese colonial period (1910-1945) (see Kearney, 1991). Japan introduced a powerful and brutal military system in the Korean colony, in order to control and exploit the former incompetent and corrupt Korean dynasty (see Kohli 2004). Finally, the country was divided immediately after this 30 years colonial period. The still existing separation of the Korean peninsula and the political and military threat by the North, are the reasons why the authoritative system is still common in South Korea (see Kang, 1991: 39). Military governments of 1960ies to 1980ies knew how to make use of this threat to legitimize their authoritative and military leadership and to mobilize the population for their purposes. Also most of Korean big enterprises, the so-called 'Chaebol', utilized the country's situation and considerably increased their

3) The term 'Ye' derives from a ritual celebrated to the honour of gods in order to ask for good fortune. This ritual should also re-establish the delicate balance between gods, nature and humans (Seelmann, 2006).

4) This concept of interpersonal relationships shaped by hierarchies has also been instrumentalized (e.g. by government and companies).

5) According to the Sapir-Whorf hypothesis, the way we think, perceive and act is strongly influenced and determined by language. Language is our filter of reality and has an impact on our perception of the world. 
economic influence with the help of the military government. The collaboration between government and business allowed big companies to profit from banking, import restriction, export support, as well as promotion of various economic sectors and industries (see Cho, 1992).

The process of South Korea's industrialization passed in an entirely different way than in Western industrial nations like Germany, where it was characterized by the principle of the 'invisible hand' of the openly competing market. In South Korea, the state involved in economics, not only regulatory but also in a planning and controlling way (see Griffin, 1988: 19, Lee, 1993: 37). Even today, this tendency is still visible in South Korea, even though influence by the state decreased considerably. Government-promoted industrialization therefore has had considerable impact on Korean economy. Industry policy of the 1970ies and 1980ies, being very benevolent to big companies and export-oriented, clearly favored producers over consumers or small (supplier) companies, which made it easy for Korean big companies to prevail against foreign competition (see Henseleit, 2001: 98). Interests of small and medium sized (supplier) companies (as well as of consumers) have played a subordinate role for a long time. This dominant position of Korean big companies, which are mostly governed by the founding family, is still a characteristic factor of Korean economy. The basic conditions of vertical relations between big companies and their suppliers can also be found in this specific feature of Korean economic development.

\section{Discussion and Limitations}

This study analyzed the different way cross $^{-}$cultural actors from Germany and Korea conceptualized the customer-supplier relation, the kinds of challenges they are confronted with and how this affects everyday business between German suppliers and Korean customers, using several case examples. Furthermore, backgrounds of cross-cultural problems and conflicts of German-Korean business relations are identified and explained. Various concepts of customer-supplier relations, such as the hierarchy in interpersonal relations, different perception of politeness, as well as country specific backgrounds were considered. Surely, the differing historic, political and socio-cultural dimensions in Germany and Korea play a major role when creating collective memory and traditional knowledge, which is applied by employees of Korean and German companies, to decide upon their way of cross-cultural acting. The diachronic perspective will be helpful to discover the backgrounds of cultural differences.

This analysis reveals that the relation between business partners in Korea has developed entirely different from Germany. The asymmetric relation between customers and suppliers emerged out of the influence of Japanese colonialism, the separation of the country, Korean War, authoritative dictatorship, and rapid economic growth. In the investigated companies, the Korean employees tended therefore to accept the asymmetric customer-supplier relation and to act according to the requirements of the respective business relation. German employees, however, felt irritated about the unequal logic of authority between customer and supplier in Korean everyday business and the resulting exaggerated expectation attitude of the Korean customers. German employees tended to refuse the requests emerging from the unequal relation between customer and supplier. As German employees could hardly perceive or understand the invisible hierarchic logic of the host country, and as their expectations to 'normal' inter-human relations were not fulfilled, they felt highly confused. The different concepts of logic of actions and

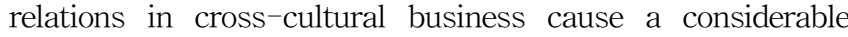
problem for participating actors, especially concerning their expectation to establish trouble-free communication and constructive projects. The results of business interactions and the approach to business partners coming from different cultures have been influenced by this fact, which often caused misunderstanding and dissatisfaction throughout cross $^{-}$cultural negotiations.

Due to the increasing global presence of Korean business and the development of global economy, business contacts between German and Korean companies are getting more frequent. ${ }^{6)}$ It is evident that the different concepts of customer-supplier relations prevalent among business actors will cause difficulties. Here, the questions are which concept of customer-supplier relation, the German or the Korean, will become dominant in future, and what kind of new variations will emerge. Further research concerning real customer-supplier interactions

6) For example, the EU and South Korea marked the first year anniversary of the implementation of the EU-South Korea Free Trade Agreement (FTA) on 1 July 2012. The agreement is the first of a new generation of free trade agreements that went further than ever before at lifting trade barriers and making it easier for European and Korean companies to do business together (European Union, 2011). 
would be required to find answers. However, it can already now be stated that it will be necessary to understand backgrounds of cultural differences to discover the resulting misunderstandings and conflicts, in order to improve the quality of German-Korean business relations.

This study has highlighted cross- ${ }^{-}$cultural challenges in international business projects between German suppliers and Korean customers. The studies on cross-cultural issues in an international business setting require a theoretical, methodical and factual foundation that enables to analyze cross-cultural actions and contexts, to assess the significance of cultural diversity as well as to inspire the global companies to operate culturally competent. Therefore, this empirical study alone is not enough to enable a discussion on a more general level of cross ${ }^{-}$cultural interactions in the international business context. Therefore, further empirical studies are necessary. It is clear that much additional work will be required before a complete understanding of Korean-German customer-supplier business relations in the shipbuilding industry. It is hoped that this study will stimulate further investigation in this research field.

\section{Acknowledgements}

This paper was supported by the Korea Maritime University Research Fund in 2011.

\section{References}

[1] Adler, N. J.(2002), "International Dimensions of Organizational Behavior", 4th ed., South-Western, Cincinnati.

[2] Adler, N. J. and Graham, J. L.(1989), "Cross -Cultural Interaction: The International Comparison Fallacy?", Journal of International Business Studies. Vol. 20, No. 3, pp. 515-537.

[3] BMVBS (Federal Ministry of Transport, Building and Urban Development)(2011), “Maritime Development Plan: Strategy for an integrated German maritime policy", Berlin.

[4] Chang, J. S.(1993), "Die koreanische Familie in Korea - im Spiegel von Frauen- und Familienbildern in der Mittelschicht", Eine empirische Untersuchung. Dissertation, Dortmund University.

[5] Cho, D. S.(1992), "From Subsidizer to Regulator The Changing Role of Korean Government", Long
Rage Planning, Vol. 25, No. 6, pp. 48-55.

[6] Dwyer, F. Robert, S., Paul H. and Oh, S.(1987), "Developing Buyer-Seller Relationships". Journal of Marketing, Vol. 51 (April 1987), pp. 11-27.

[7] Ebert, H.(2003), "Hoeflichkeit und Respekt in der Unternehmenskommunikation", Wege zu einem professionellen Beziehungsmanagement. Luchterhand, Muenchen,

[8] European Union(2011), "EU-Korea Free Trade Agreement in practice", Luxembourg.

[9] Gaugler, E.(1969), "Elemente des kooperativen Fuehrungsstils", Gaugler, E. (ed.): Verantwortliche Betriebsfuehrung. C.E.Poeschel Verlag, Stuttgart, pp. 114-128.

[10] Graham, J. L.(1984), “A Comparison of Japanese and American Business Negotiations", International Journal of Research in Marketing, Vol. 1, No. 1, pp. 51-68.

[11] Graham, J. L.(1985), "Cross-Cultural Marketing Negotiations: A Laboratory Experiment", Marketing Science, Vol. 4, No. 2, pp. 130-146.

[12] Graham, J. L., Kim, D. K., Lin, C. Y. and Robinson, M.(1988), "Buyer-Seller Negotiations Around the Pacific Rim: Differences in Fundamental Exchange Processes". Journal of Consumer Research, Vol. 15, Juni 1988. pp. 48-54.

[13] Griffin, T. J.(1988), "Korea. The Tiger Economy“, Prentice-Hall, London.

[14] Henseleit, R.(2001), "Aenderung des Verbraucherverhaltens in Korea", Huenerberg, Reinhard (ed.): "Sued-Korea als Auslandsmarkt: Marktbedingungen und internationales Marketing", Deutscher Universitaets-Verlag, Wiesbaden, pp. 85-103.

[15] Kale, S. H. and Barnes, J. W.(1992) "Understanding the Domain of Cross-National Buyer-Seller Interactions", Journal of International Business Studies, Vol. 23, No. 1, pp. 101-132.

[16] Kang, T.W.(1991), "Wirtschaftsmacht Korea: Was Sie ueber Europas naechsten Konkurrenten wissen muessen", Campus Verlag, Frankfurt/Main and New York.

[17] Kearney, R. P.(1991), "The Warrior Worker. The Challenge of the Korean Way of Working. The History and Challenge of South Korea's Economic Miracle", Henry Holt \& Co., New York.

[18] Kohli, A.(2004),"State-Directed Development. Political Power and Industrialization in the Global Periphery", Cambridge University Press, Cambridge. 
[19] Kotthoff, H.(2001), "Pluri-local social spaces in global operating German companies", Pries, Ludger (ed.): "New Transnational Social Spaces. International migration and transnational companies in the early twenty-first century", Routledge, London \& New York, pp. 134-144.

[20] Lamming, R.(2000), "Japanese Supply Chain Relationship in Recession", Long Range Planning, Vol. 33, No. 6, pp. $757-778$.

[21] Lee, J. Y.(1993), "Entwicklung und Fuehrung Suedkoreanischer Unternehmen - Insbesondere Die Struktur: Organisation und Strategie Suedkoreanischer Unternehmensgruppen Chaebol", Dissertation, Goettingen University.

[22] Mayring, P.(2002), "Einfuehrung in die qualitative Sozialforschung: Eine Anleitung $\mathrm{zu}$ qualitativem Denken", 5th ed.,, Beltz, Weinheim.

[23] Miles, M. B. and Huberman, A. M.(1994), "Qualitative Data Analysis: An Expanded Sourcebook,", 2nd ed., Sage, Thousand Oaks.

[24] Moosmueller, A.(2003), "Interkulturelle Routinen in deutschen und amerikanischen Unternehmen in Japan", Deutschen Institut fuer Japanstudien (ed.): Japanstudien. Bd. 15, Muenchen, pp. 199-218.

[25] Nees, G.(2000), "Germany. Unraveling An Enigma", Intercultural Press, Boston \& London.

[26] Perlmutter, H. V.(1969), "The Tortuous Evolution of the Multinational Corporation", Columbia Journal of World Business, January-Feburary 1969, pp. 9-18.

[27] Schoefer, H.(2001), "Die Unternehmensstrategie der FAG Kugelfischer Georg Schaefer AG in Korea", Huenerberg, R. (ed.): "Sued-Korea als Auslandsmarkt: Marktbedingungen und internationales Marketing", Deutscher Universitaets-Verlag, Wiesbaden, pp. 251273.

[28] Seelmann, H. N.(2006), "Harmonie und Hierarchie: Warum Asiaten einen anderen Begriff von Hoeflichkeit besitzen", Neue Zuercher Zeitung. 15.12.2006.

[29] Skarmeas, D., Katsikeas, C. S. and Schlegelmilch, B. B.(2002), "Drivers of Commitment and its Impact on Performance in Cross-Cultural Buyer-Seller Relationships: The Importer's Perspective", Journal of International Business Studies. Vol. 33, No. 4, pp. 757-783.

[30] Weber, T.(2006), “An exhaustive analysis of employment trends in all sectors related to sea or using sea resources: Country Report - Germany", European Commission, DG Fisheries and Maritime Affairs.

[31] Whorf, B. L.(1964), "Language, Thought, and Reality:
Selected Writings of Benjamin Lee Whorf", MIT Press, Massachusetts.

Received 1 November 2012

Revised 21 December 2012

Accepted 26 December 2012 